\title{
Sjiele Sacrifices, Odin Treasures and Saami Graves?
}

\author{
By INGER ZACHRISSON
}

In this lecture I should first like to comment upon some new results which are of interest for the History of Religion from my dissertation on what I prefer to call the Saami metal deposits (Zachrisson 1984). These wellknown "Finds from Lapp Places of Sacrifice", objects from the Viking Age and Early Middle Ages, were mostly found in northern Sweden (Hallström 1932; Serning 1956; Fjellström 1962). I then intend to present a new research project, dealing with prehistoric and medieval Saami graves from the south Saami area.

The fact that the metal objects have been lying among antlers and bones on the sacrificial sites is proved by Gustaf Hallström's report from his archaeological excavation in 1915 at Unna Saiva, a sacrificial site in Lapland, showing that the artefacts here were found in a layer of antlers. A silver earring from a well known Saami "sacrificial cave" at Ukonsaari, an island in L. Enare in northern Finland, was embedded in burnt bones. Christian Carpelan's recent excavations at a Saami dwelling-site from the 15 th-16th c. by the same lake have revealed piles of antlers and bones, metal objects among them, possibly sacrifices.

The circumstances in which the large and much discussed Grăträsk find from northern Sweden was discovered-formerly interpreted as a sacrificial site, but without antlers or bones-have now been studied for the first time. According to old documents, the artefacts were situated in a "box" of logs, submerged by the shore of a lake, and attached to the bottom. The artefacts are all typical of the Saami sacrificial sites, and they have suspension holes and threads of the same kind as these finds. They must derive from sacrificial sites. The only plausible interpretation of this unique find is that it is a thief's cache. One or more sacrificial sites were plundered, and objects of pewter, bronze and silver from them-no iron, however, in contrast to other such sites-were collected and hidden under water in the box, probably on several occasions. All this indicates that the thief was not a Saami.

The artefacts from Gråträsk and the sacrificial sites had been suspended on woollen threads and not thongs of leather, the most common material 
according to Saami grave finds. Was wool used for a practical reason or for a ritual purpose-perhaps the wool in itself was a sacrifice?

The most typical artefacts in the Saami metal deposits are the cast pendants of pewter, ca 500 in all. These have the character of amulets. They could have been suspended from Saami drums or personal belongings before being sacrificed. It has now been possible to date them to the first half of the 14th c., whereas they had formerly been attributed to the 11 th-12th centuries. Their manufacture, metal composition and ornamentation show them to be of Saami fabrication.

One question which has not really been discussed before is why the Saamis began to sacrifice metal artefacts during the Viking Age. Was it because at this time metal objects became abundant in the North? Or is Knut Odner right in suggesting (1983) that it could be the result of influences from Nordic religious concepts? From southern Sweden we know of sacrificial finds consisting of animal bones, weapons and other artefacts, mostly from the early Iron Age. From Gotland, however, even some Viking Age finds of this kind are known.

If the latter explanation is correct, the Saami custom of sacrificing metal objects-together with the traditional antlers - could be another survival of traits of the Nordic Viking Age culture in the Saami culture. Other characteristics of the Nordic and Eastern peoples of the Viking Age, in ornamentation, dress etc., were taken over by the Saamis and gradually came to be regarded as something typically Saami. This is what the ethnologists call "culture fixation" (Erixon 1945). It shows that the Viking Age was a boom period for the Saamis, probably based on the fur trade.

I have also put forward a new hypothesis about why the Saamis ceased to sacrifice metal objects in the middle of the 14 th c., the time to which the most recent datable foreign objects in the Saami metal deposits can be dated. Most of these reached the West Saami area from the Norwegian coast. At the beginning of the 14 th $\mathrm{c}$., a severe deterioration of the climate took place in Norway, as in the whole of northern Europe. In 1349-50 the country was struck by the Black Death, harder than its neighbours, as it seems. All this caused an agrarian crisis which laid waste between half and threequarters of the farmsteads in Norway. Russian chronicles from Novgorod also mention that the Black Death several times struck this vast empire with its influence on Saami areas and as far away as northern Norway (Akiander 1848).

It is in the light of these facts that the drastic break in the continuity of the Saami metal deposits must be seen. This sudden end of many hundreds of years of tradition must have had serious causes. The sacrificial sites continued to be used, but now without any quantity of metal artefacts being 
sacrificed. I interpret this as a result of the Black Death. The trade contacts of the Saamis must have been broken, and it is likely that they themselves suffered from the Black Death. The custom of sacrificing metal objects seems, however, to have survived on a small scale among the Saamis until recent times. The Saami metal deposits could be early examples of socalled Sjiele sacrifices (Zachrisson 1984; cf. Mebius 1968; cf. Mebius 1972).

Furthermore, other kinds of metal deposits from the period 1000-1350 have been found in Saami regions far away from the Norwegian settled areas in northern Fenno-Scandia, i.e. metal deposits quite different in character from those mentioned above: silyer hoards, consisting of one or several pieces of jewelry. They are characterized by pendants and rings. Many of the silver objects have their only known equivalents in the Saami metal deposits and Saami graves of northern Norway. It is significant that the distribution of the silver deposits is not the same as that of the Saami metal deposits. I am of the opinion that some of the former could also have been deposited by Saamis.

Should the silver deposits be interpreted as hoards or sacrifices? Rings always seem to have been objects of treasure and cult. Deposited gold and silver rings have often been shown to be sacrifices, and finds of a few precious artefacts are often looked upon as sacrifices and not treasure hoards. Such things have not been found in graves (Geisslinger 1970; Capelle 1970).

It is also possible that some of the silver jewelry in question was deposited in accordance with the so-called Odin's Law. Snorre Sturlasson writes in the 13th c. in Heimskringla, Chapter 8, about Odin establishing laws: "He said that every man should come to Valhalla with the riches that he had with him on the pyre; he should also benefit from the things that he himself had buried in the earth." Examples of this primarily east Scandinavian custom are also to be found in other west Scandinavian written sources, for example in Egil Skallagrimsson's Saga. Both Skallagrim and his son Egil, in his turn, hid their silver when they felt death approaching.

The same custom was alive among Saamis in Sweden and Norway as late as the 18th and 19th centuries. Leem writes from Norway of a Saami who, asked why he buried his money, answered: "If my money after my death came into the hands of others, then what should I live on in the Land of Death?' Högström relates from Swedish Lapland, also from the 18th century, that the Saamis bury their money "but hide nothing except what they themselves have buried at a certain place on their land, which they are not allowed to reveal or touch themselves". In 1973 von Düben quotes the above authors and adds that "such burials are still taking place in Stensele, Arjeplog and Jokkmokk'. 


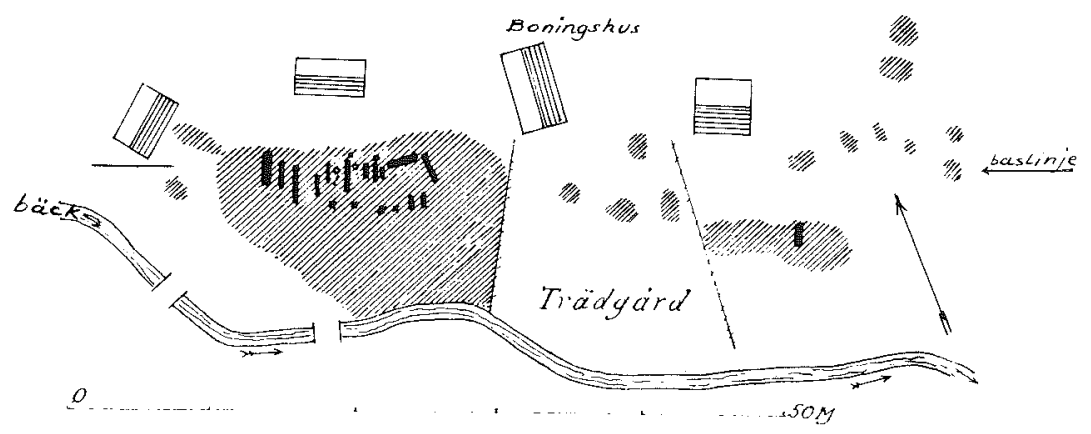

Fig. 1. The grave field at Vivallen in north-west Härjedalen, from the 11th-12th c. Plan by Gustaf Hallström, 1913.

This is the point where I should like to present a new Norwegian-Swedish archaeological-osteological research project. Our aim is to answer the much debated question "Were there Saamis in Hedmark, Härjedalen and Jämtland during the Viking and Middle Ages?" Some are of the opinion that the Saamis originally lived in central Sweden and southern Norway, and were then pushed back northwards, others that they did not until recent times spread as far south as northern Dalecarlia and L. Femunden (in Norway). Today, this last view is held especially by the Norwegian historian, Jörn Sandnes. He has also put forward the theory that the Saamis would have spread southwards in the vacuum following the Black Death in 1349-50 (Sandnes 1973).

There are, however, indications in the archaeological material that the history of the Saamis in southern Norway and central Sweden is a long one. In the new project we will now investigate this further: on the Norwegian side Guro Syversen, Oslo; from Sweden, Elisabeth Iregren, the osteologist, and myself, both working at the Museum of National Antiquities (Historiska Museet) in Stockholm, and Jan Sundström at Jämtlands läns museum in Östersund.

The starting-points for our work are the known finds, combined with new field investigations. The study of the grave material seems to be a fruitful means of starting this work of determining the ethnic affiliation of archaeological and anthropological material-the first time a research project in Sweden has had this as its main purpose.

As our investigation area in Sweden we have chosen an area of $60 \times 20 \mathrm{~km}$ at the sources of R. Ljusnan in north west Härjedalen. In the centre is situated the grave field of Vivallen, $5 \mathrm{~km} \mathrm{NW}$ of Funäsdalen. Twenty 


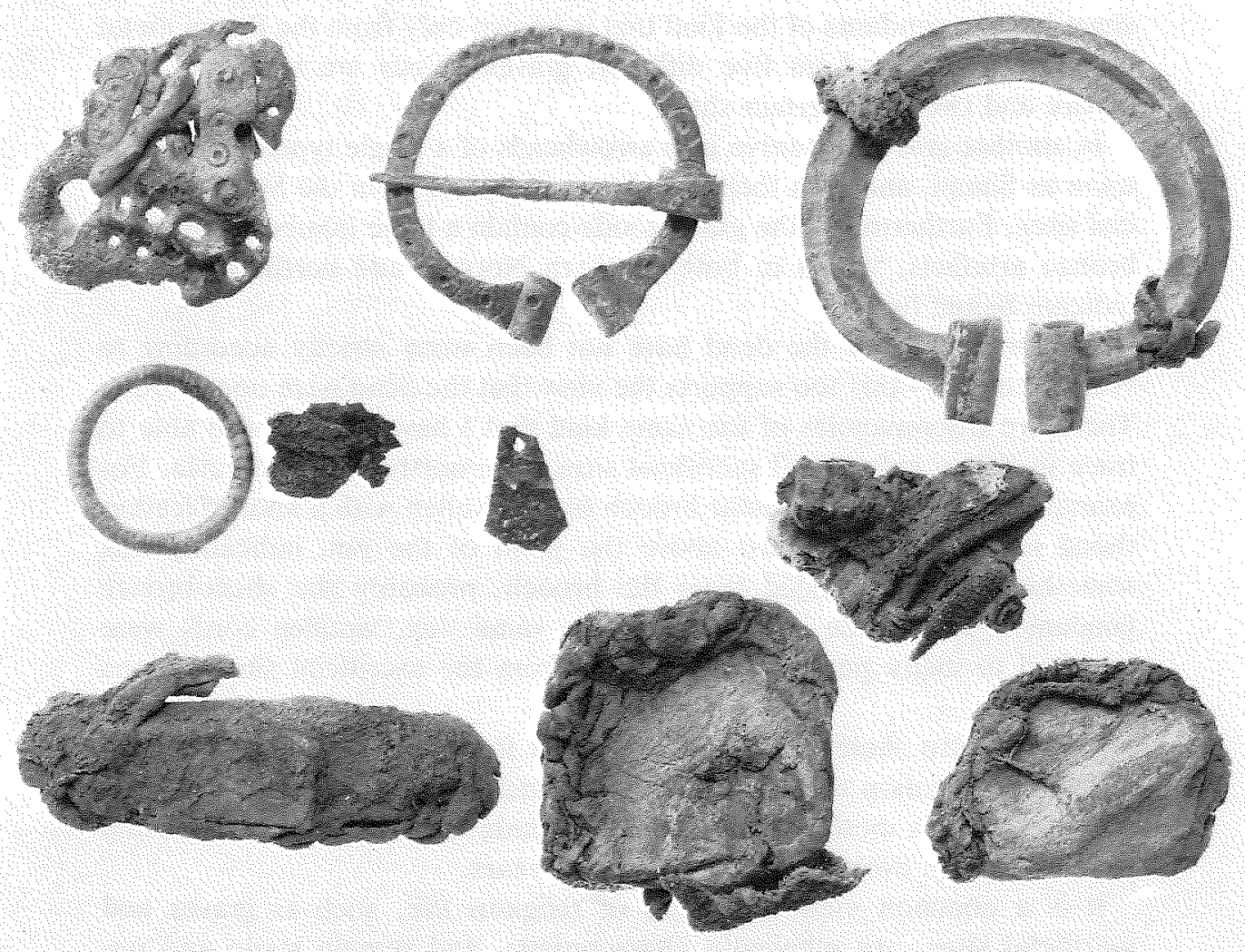

Fig. 2. Artefacts from the Vivallen graves, inter alia the three ring-shaped brooches of bronze, one of the trapezoid pendants of sheet bronze, and (below) three amulets, sewn up in leather (a pendant, a piece of bronze sheet, and a piece of wood). 1:1. Photo Gunnel Jansson.

graves, mostly from the 11th and 12th c., were excavated here by Gustaf Hallström in 1913 (Hallström 1944). These were skeleton graves, situated in two rows in a slope facing south, by a small stream. They were lying in flat ground, oriented north-south, and so close together that they must have had some markers above ground, so as not to interfere with each other. The dead had been tightly wrapped in mummy-like shrouds of birch-bark. This had made it possible to place them in the very narrow, rectangular, shallow pits in the sand, all of which except one were shaped like a trough. All this is characteristic of Saami pre-Christian burial custom as we know it from the Iron and Middle Ages-up to more recent times. 
There are also other indications that this is a Saami grave field. Seven sheet-bronze pendants of the kind that is known only from the Saami metal deposits were found (in five different graves). Four are trapezoid, one square and two of uncertain shape.

In another grave lay twelve iron arrowheads of a single type, also looked upon as Saami, and with their closest counterparts from the Saami sacrificial sites. Furthermore, the grave goods contain a large number of Eastern bronze artefacts, which in both northern Norway and northern Sweden indicate Saami finds.

The ornaments of the dead have not been worn strictly according to Nordic custom - this too supports the view that the dead were non-Nordic. There are discrepancies of the same kind that I have earlier been able to trace in Saami graves and sacrificial sites from northern Scandinavia. For example, there is a penannular brooch from Vivallen with a knot of leather thong round the frame just above the point of the pin, indicating that something was suspended from the brooch, probably the sheet-bronze pendant found beside it. In exactly the same way, woollen cords were attached to many penannular brooches from the sacrificial site at Unna Saiva.

There is also skeletal material preserved from Vivallen. The anthropological investigation of this will above all include a study of the so-called discrete traits, a method of establishing ethnic affiliation and relationship which has been evolved during the last 15 years.

It is a common view that signs of religious life, such as graves and sacrificial sites, are ethnically characteristic, and remain static and unchanged for a long time. However, the oldest known typical Saami grave in Sweden is from the 14th c., from Tärna in west Lapland (Zachrisson 1986). What the Saami graves in most of Lapland looked like before that, we do not know. Maybe the dead were laid out on or above the ground (Storå 1971).

South of Lapland we know of many graves from the period ca A.D. $1-1050$ from the interior, far away from the agrarian Nordic settlement areas, often situated on the dwelling sites of the hunter-gatherer culture. These are the so-called Lake Graves, known from the sources of the R. Ångermanälven in the north to Dalecarlia in the south. They have been interpreted as belonging to a hunter-gatherer culture, or to the Nordic agrarian culture. They can be divided into three groups (Baudou 1978).

The first and oldest consists of grave fields with cremation graves in triangular or circular stone settings. Two of the most thoroughly investigated of these are the ones at Smalnäset and Krankmårtenhögen, both situated in north-west Härjedalen. Some of their graves were covered with a layer of 


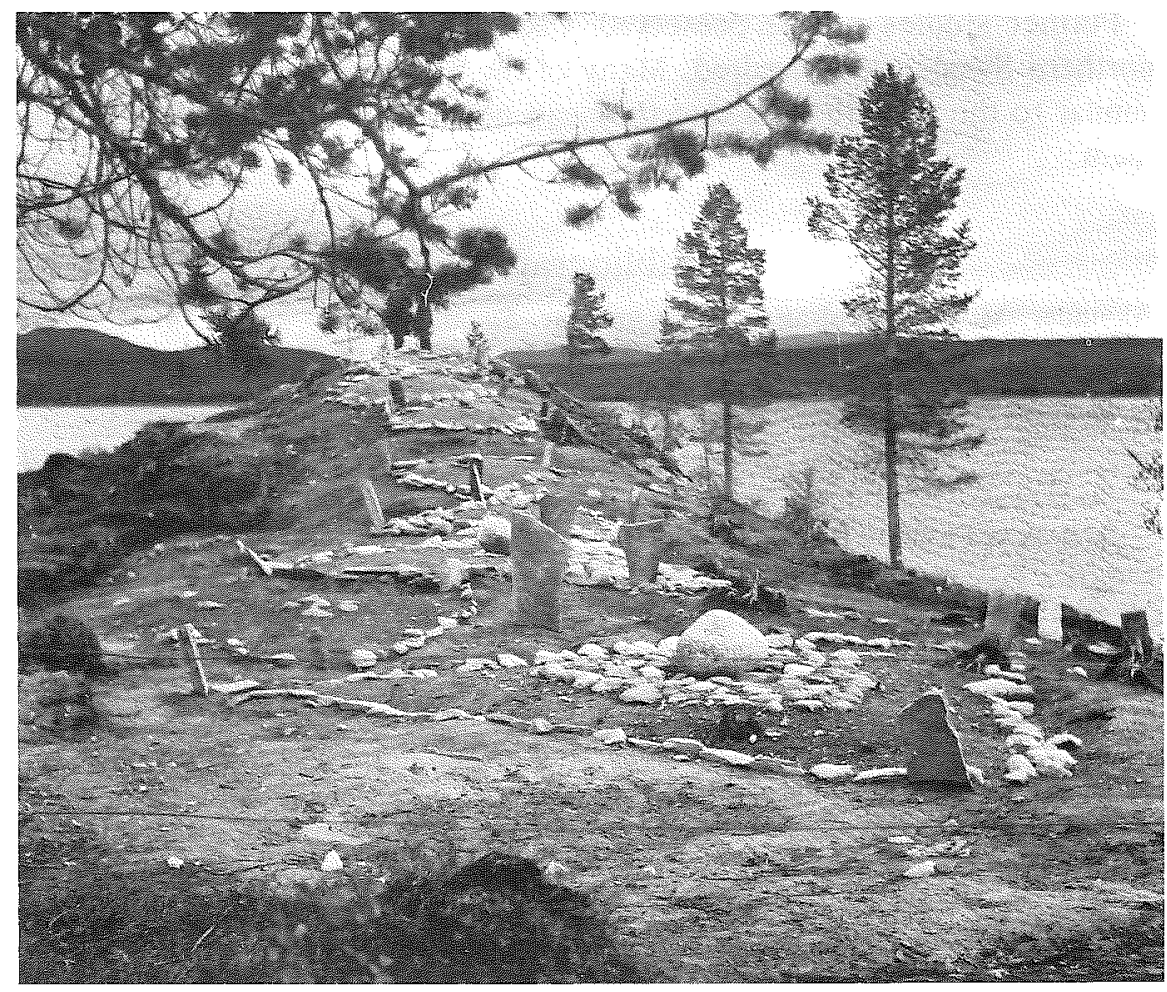

Fig. 3. Krankmårtenhögen, a grave field in north-west Härjedalen from the time of the birth of Christ. Photo Göran Stolpe.

antlers of elk and reindeer, interpreted as sacrifices of the hunter-gatherer culture (Ambrosiani \& Iregren \& Lahtiperä 1984).

The second group consists of stone settings, many of them in Härjedalen and Jämtland. They are mostly cairns. It is typical how often the word "Finn" or "Lapp" (i.e. Saami) can be attached to them by tradition, or how it is said that Saamis have been buried at these places (Selinge 1976).

The third, Viking Age, group, might also belong to the hunter-gatherer culture. I think it reasonable to call this culture Saami at least from the beginning of the 1st century A.D..

If the above is correct, it means that some Saamis during the Iron and Early Middle Ages borrowed their burial customs from neighbouring peoples. Odner has arrived at the same conclusion after studying graves from Norway and Finland. According to him, it was not until ca A.D. 1500 that a typical Saami burial custom had spread over the whole Saami area (Odner 1983). 
Further studies of the preserved Viking Age and Medieval graves in northern Sweden are required. Many of the Saami graves are probably so similar to the Nordic ones that they can not easily be differentiated from them.

\section{Bibliography}

Akiander, M. 1848. Utdrag ur ryska annaler. Suomi.

Ambrosiani, B. \& Iregren, E. \& Lahtiperä, P. 1984. Gravfält i fångstmarken. (Riksantikvarieämbetet och Statens historiska museer. Rapport 1984, 6.) Stockholm.

Baudou, E. 1978. Archaeological investigations at L. Holmsjön, Medelpad. Archaeological and palaeological studies in Medelpad, N. Sweden. (Early Norrland 11.) Stockholm.

Capelle, T. 1970. Ringopfer. Heiligtümer und Opferplätze in Mittel- und Nordeuropa. (Abhandlungen der Akademie der Wissenschaften in Göttingen. Phil.-hist. Klasse 3, 74.) Göttingen.

Erixon, S. 1945. Svenska kulturgränser och kulturprovinser. (Kungl. Gustaf Adolfs Akademiens småskrifter 1.) Stockholm.

Fjellström, Ph. 1962. Lapskt silver 1-2. (Skrifter utg. genom Landsmåls- och Folkminnesarkivet i Uppsala C, 3.) Uppsala.

Geisslinger, H. 1970. Soziale Schichtungen in den Opferdepots der Völkerwanderungszeit. Heiligtümer und Opferplätze in Mittel- und Nordeuropa. (Abhandlungen der Akademie der Wissenschaften in Göttingen. Phil.-hist. Klasse. 3, 74.) Göttingen.

Hallström, G. 1932. Lapska offerplatser. Arkeologiska studier tillägnade HKH Kronprins Gustaf Adolf. Stockholm.

- 1944. Gravfältet på Vivallen i Funäsdalen. Heimbygdas tidskrift. (Fornvårdaren 8.) Östersund.

Mebius, H. 1968. Värrō. (Skrifter utg. av Religionshistoriska institutionen i Uppsala, Hum. fak., 5.) Uppsala.

- 1972. Sjiele. (Skrifter utg. av Religionshistoriska institutionen i Uppsala, Hum. fak., 9.) Uppsala.

Odner, K. 1983. Finner og terfinner. (Oslo occasional papers in social anthropology 9.) Oslo.

Sandnes, J. 1973. Om samenes utbredelse mot s $\phi \mathrm{r}$ i eldre tid. Historisk Tidsskrift 2.

Selinge, K.-G. 1976. Människan i landskapet. (Fornvårdaren 14.) Östersund.

Serning, I. 1956. Lapska offerplatsfynd från järnålder och medeltid i de suenska lappmarkerna. (Acta Lapponica 11.) Stockholm.

Storå, N. 1971. Burial customs of the Skolt Lapps. (FF Communications 89, 210.) Helsinki.

Zachrisson, I. 1984. De samiska metalldepåerna år 1000-1350 i ljuset av fyndet från Mörtträsket, Lappland. (Archaeology and environment 3.) Umeå.

- 1986. En samisk grav frăn 1300-talet vid Gäutavardo. Studier i norrländsk forntid II. (Acta Bothniensia Occidentalis 8.) Umeå. 